Creative Commons User License: CC BY-NC-ND

Abstracted by: EBSCOhost, Electronic Journals Service (EJS),

Google Scholar, Journal Seek, Scientific Commons,

Food and Agricultural Organization (FAO), CABI and Scopus

http://eoi.citefactor.org/10.11226/v23i1
Journal of Agricultural Extension

Vol. 23 (1) January, 2019

ISSN(e): 24086851; ISSN(Print); 1119944X

http://journal.aesonnigeria.org

http://www.ajol.info/index.php/iae

Email: editorinchief@aesonnigeria.org

\title{
Perceptions of Undergraduate Students to Practical Agriculture Experience at the University of Fort Hare, South Africa
}

https://dx.doi.org/10.4314/jae.v23i1.18

Yusuf, Shehu Folaranmi. G.

Department of Agricultural Economics and Extension

University of forte Hare, Alice, South Africa

fyusuf@ufh.ac.za; +27(0)849913664

Popoola, Oluwabunmi. 0.

Department of Agricultural Economics and Extension

University of forte Hare, Alice, South Africa

sopeinoluwabunmi@gmail.com; +27(0)638480276

\section{Olutegbe, Nathaniel S.}

Department of Agricultural Extension and Rural Development

University of Ibadan, Ibadan Nigeria

siji004u@yaho.com; +2347032077856

\section{Abstract}

The study examined perceptions of final year students of agriculture at the University of Fort Hare to practical agricultural experience. A multi-stage sampling procedure was used to obtain data from 278 which were analysed, using descriptive and inferential statistics. The study reveals that more than half (55.0\%) had favourable perceptions of practical agriculture experience (PAE). However, only about half (51.1\%) expressed a high level of satisfaction. The majority (61.9\%) were in favour of on-the-farm internships. There was a significant relationship between respondents' perceptions regarding improved performance $(r=0.276)$, general attitude to PAE $(r=0.438)$ and overall satisfaction with the PAE programme. Based on its findings, this study has implications for the evaluation process of the programme and suggests that the design of the PAE should center around on-farm activities based on a specific number of weeks for internships on commercial farms. This will provide the reallife experiential learning that could stimulate students to venture into practical farming post-graduation.

Key words: Curriculum, Academic performance, training, learning, skills, employability.

\section{Introduction}

Education is vital for human and natural resource development, individual behavioural and attitude change and, enhancement of participatory skills in people (Kipkeme, et al., 2015). Danilevičius (2013) emphasized the importance of strengthening the link between learners in agricultural schools with specific professions as it facilitates occupational aptitude and meaningful qualification for precise occupational activities, that serves as primacy of school curricula to any educational system (Richmond, 2018). It is crucial to boost universities curriculum to accommodate intensive and extensive practical learnings that provide a strong support to the theories taught within the four walls of the class rooms. Williams (2015) 
Creative Commons User License: CC BY-NC-ND

Abstracted by: EBSCOhost, Electronic Journals Service (EJS),

Google Scholar, Journal Seek, Scientific Commons,

Food and Agricultural Organization (FAO), CABI and Scopus
Journal of Agricultural Extension

Vol. 23 (1) January, 2019

ISSN(e): 24086851; ISSN(Print); 1119944X

http://journal.aesonnigeria.org

http://www.ajol.info/index.php/iae

Email: editorinchief@aesonnigeria.org

indicates that while theory is profound as a platform for any productive practical training, it should not be made dominant. "Knowledge one has acquired without sufficient structure to tie it together is knowledge that is likely to be forgotten" (Richmond, 2018). According to Reece and Walker (2016) there are students whose learning abilities are better enhanced through direct or practical experiences. Such 'real-life' learning experiences are fundamental for students in the field of agriculture.

The Department of Agricultural Sciences, University of Fort Hare (UFH), Eastern Cape Province, South Africa instituted practical agricultural experience (PAE) for all third-year undergraduate agricultural students. It provides the students with practical hands-on experience of farming activities. The PAE is undertaken during academic recess under the supervision of authorised persons, institutions or projects. Since the incorporation of PAE into the curriculum of the university, there has been scant literature to indicate the perceptions of students towards the training programme. This information would be particularly valuable in view of the poor attitudes toward agriculture generally displayed by young people in South Africa. For the youth to participate in farming, a pragmatic and business-oriented farm training is important. These trainings could be in forms of 'agriculture-orientated internships, offcampus service-learning opportunities, cooperative learning experiences with the agriculture industry, student-led seminars, and self-directed practicums' (Niewolny et al., 2016). The literature has identified positive correlations between theory and practice and why practical experiential learning should be infused into agriculture curricula (Tukundane et al., 2015; Swarts \& Aliber, 2013; The African Economic Outlook, 2012; The United Nations Educational, Scientific and Cultural Organization, UNESCO, 2012).

The South African National Development Plan (NDP) and Vision 2030 emphasized the potential of agriculture to create one million new jobs by 2030 , of which about half would be in the smallholder sector, largely meaning self-employment. For this to materialise, the skills for practical agricultural knowledge must be well embedded in the training curricula of universities. According to Saliu, Onuche and Abubakar (2016), practical farming has a lot to do with the kinds of skills and entrepreneurial knowledge acquired that may be used in real-life situations. Based on the above considerations, the researcher determined (1) the perceptions of agricultural undergraduates to PAE at the University of Fort Hare (2) the attitudinal behaviour of the students towards PAE. We sought to ascertain (3) whether PAE is meeting students' aspirations and helping with future work challenges, and (4) the level of students' satisfaction regarding $\mathrm{PAE}$.

Undoubtedly, learning develops a person's functional, analytical and leadership capacities, unlocking diverse opportunities for use within the labour market and in any chosen occupational field (Onanuga, 2015). The role of the universities in facilitating such capacity development is unquestionably critical. Tertiary institutions are especially tasked with producing extremely proficient human resources to attain national economic development goals in their various sectors and sub-sectors (Mojarradi \& Karamidehkordi, 2016). That higher education is associated with human capital development, economic growth and social progress has long been established (Pouris and Inglesi-Lotz, 2014; Wang and Liu, 2016). 
Creative Commons User License: CC BY-NC-ND

Abstracted by: EBSCOhost, Electronic Journals Service (EJS),

Google Scholar, Journal Seek, Scientific Commons,

Food and Agricultural Organization (FAO), CABI and Scopus

http://eoi.citefactor.org/10.11226/v23i1
Journal of Agricultural Extension

Vol. 23 (1) January, 2019

ISSN(e): 24086851; ISSN(Print); 1119944X

http://journal.aesonnigeria.org

http://www.ajol.info/index.php/iae

Email: editorinchief@aesonnigeria.org

There is no specific dialogue or all-encompassing view regarding what universities should produce. However, employers expect graduates to possess certain attributes which includes:

communicative ability, independence, confidence, proactive, team player, discipline, motivated and a positive attitude (Abidin, Jamil \& Abdullah, 2017). Rodzalan, and Saat (2012) points to numerous literature which agrees that students must acquire technical, employability, generic and transferable skills. According to Tang (2012), graduate's must meet up with two primary requirements - ability to accumulate knowledge and the aptitude to blend acquired knowledge with context.

According to Mojarradi and Karamidehkordi (2016), learning processes must take into account the ability to work collaboratively, think innovatively and solve problems in a variety of different ways. One way these skills are acquired is through expertise in the theoretical component of the higher institution's curriculum. Many educational institutions have incorporated practical and technical subjects in their curriculums (Hulela, 2017); giving students opportunities to transmit their theoretical knowledge to practice through practical training programmes (Rodzalan \& Saat, 2012). This has enhanced the quality of their programmes (Mojarradi \& Karamidehkordi, 2016). Limitations in the design, content and delivery of the agricultural curriculum form part of the many problems limiting universities' capacity to meet the demands of the agricultural sector, including the skills shortage (Acuña et al., 2014). In the opinion of Ayanda, Yusuf and Salawu (2013), the inclusion of practical farm training in agricultural curricula has helped address some of these shortcomings, as the acquisition of practical skills has broadened graduates' skills in agriculture. Such practices, known as placement, internship, cooperative education, experiential education, or work-integrated learning in different academic institutions, are believed to be important to help students gain hands-on experience in the workplace, practice textbook theories and skills, and reflect upon their future career development' (Mojarradi \& Karamidehkordi, 2016).

Lenke (2015) posits that 'training for proficiency in farming' should be the adopted credo for all agricultural educational programmes. A very significant component of agricultural training is the development of practical skills in students (William, 2015; Deegan, Wims \& Pettit, 2016). In the opinion of William (2015), the timing (quantity and quality) allotted for practical training may determine the effectiveness of such training on the trainee; the author consequently advocated for an increase in the practical training time assigned in an educational curriculum. Therefore, obtaining a qualification at a university goes beyond acquiring new theoretical knowledge; it extends to honing the skills required to be professionally efficacious. According to Richmond (2018) 'the best way to create interest in a subject is to render it worth knowing, meaning to make the knowledge gained usable in one's thinking beyond the situation in which the learning has occurred'.

\section{Methodology}

The population was $f$ all final-year undergraduate agricultural students (Level 300) - both B. Agriculture and B.Sc. Agriculture students in the academic years 2013-2016. Data were received from 334 students. Fifty-six (16.77\%) questionnaires were rejected for containing excessive missing data and poor data entries. Respondents were sampled in their final year post exposure to the PAE programme. The internal consistency and reliability of the instrument was 0.79 Cronbach's Coefficient for the perceptions of the students regarding PAE; other 
Creative Commons User License: CC BY-NC-ND

Abstracted by: EBSCOhost, Electronic Journals Service (EJS),

Google Scholar, Journal Seek, Scientific Commons,

Food and Agricultural Organization (FAO), CABI and Scopus

http://eoi.citefactor.org/10.11226/v23i1
Journal of Agricultural Extension

Vol. 23 (1) January, 2019

ISSN(e): 24086851; ISSN(Print); 1119944X

http://journal.aesonnigeria.org

http://www.ajol.info/index.php/iae

Email: editorinchief@aesonnigeria.org

measurements were 0.83 (the involvement of family members in farming); 0.86 (the perceptions of students on the satisfaction from the training); 0.82 (the perceptions about improving PAE); and 0.79 (the perceptions regarding improved academic performance).

A five-point Likert-type scale, with response range from 'strongly agree' (5); 'agree' (4); 'undecided' (3); 'disagree' (2) to 'strongly disagree' (1), was used to assess respondents' perceptions. For each of these variables, responses were categorised into two groups; high and low (for perceived satisfaction and involvement) or favourable and unfavourable (for perception of PAE and improved academic performance), using the mean score for each variable as the benchmark. Total and mean perception scores were computed after which a cut-off means score of $3.5[(1+2+3+4+5) / 5+0.5)]$ was used to differentiate between high and low or favourable and unfavourable. Mean scores match of $x \geq 3.5$ rated high or favourable and $x<3.5$ rated low or unfavourable. Descriptive statistical analysis such as frequency, percentage and mean were used, while the Pearson's Product Moment Correlation was used to analyse the hypothesis, using the IBM-SPSS Statistics version 20 (2015).

\section{Results and Discussion}

\section{Socio-demographic Characteristics of Respondents}

Table 1 shows that the majority (56.47\%) of the students were male, with a mean age of 23 years, the modal $(92.09 \%)$ age group being $20-25$ years. A very high proportion $(97.84 \%)$ indicated that at least one of their family members was studying agriculture in the school.

Table 1: Respondents' personal characteristics

\begin{tabular}{lll}
\hline Variable & $(\%)$ & Mean \\
\hline Programme & & \\
B. Agriculture & 61.5 & \\
B Sc. Agriculture & 38.5 & \\
Sex & & \\
Male & 56.5 & $22.79 \pm 2.53$ \\
Female & 43.5 & \\
Age & & \\
$20-25$ & 92.0 & \\
$26-30$ & 5.8 & \\
$>30$ & 6.2 & \\
Place of domicile & & \\
Rural & 65.8 & \\
Urban & 20.5 & \\
Peri-urban & 13.7 & \\
Siblings studying & & \\
agriculture & \\
Yes & 97 \\
No & 2.16
\end{tabular}

Source: Field survey (2018) 
Creative Commons User License: CC BY-NC-ND

Abstracted by: EBSCOhost, Electronic Journals Service (EJS),

Google Scholar, Journal Seek, Scientific Commons,

Food and Agricultural Organization (FAO), CABI and Scopus

http://eoi.citefactor.org/10.11226/v23i1
Journal of Agricultural Extension

Vol. 23 (1) January, 2019

ISSN(e): 24086851; ISSN(Print); 1119944X

http://journal.aesonnigeria.org

http://www.ajol.info/index.php/jae

Email: editorinchief@aesonnigeria.org

The majority $(97.84 \%)$ of respondents indicated that at least one of their siblings was studying agriculture in an educational institution. It suggests that agriculture is still a favoured course of study to many young people in rural settings. Mojarradi and Karamidehkordi (2016) posited that students coming from rural settings have a comparative advantage of previous exposure to farming. Informal, experiential learning should be related to the theoretical, scientific teaching of the university, and give practical expression to the concepts taught in agriculture curricula.

\section{Perceptions of Practical Agricultural Experience (PAE)}

Table 2 reflects the generally favourable disposition among the respondents towards PAE. More than half (52.9\%) strongly agreed that PAE contributed to their practical skills acquisition. The majority ( $82.6 \%)$ agreed that the training provided them with skills that they were likely to require post-graduation, while $82.2 \%$ agreed that the training provided industrial skills and experience relevant to their courses of study. A grand mean of 3.67 further confirms that on average, the disposition of the students towards PAE was positive.

\section{Table 2: Perceptions regarding PAE}

\begin{tabular}{|c|c|c|}
\hline Perceptions regarding practical agricultural experience (PAE) & Mean & SD \\
\hline The PAE contributes to my practical acquisition of skills. & 4.40 & 0.4 \\
\hline The timing of the training was appropriate for experiential learning to take place. & 4.10 & 3.6 \\
\hline The facilitators are very skillful in handling the training programme. & 4.18 & 1.8 \\
\hline Students were provided with adequate working tools. & 3.13 & 19.1 \\
\hline The method of training was by lecture rather than by practical activities. & 2.89 & 15.8 \\
\hline The numbers of days for the training is sufficient for competency in my area of study. & 3.60 & 7.6 \\
\hline The monitoring and evaluation by the university is excellent. & 3.45 & 12.2 \\
\hline I found it difficult to grasp the technical language used during the training. & 3.86 & 30.6 \\
\hline The training does not relate to the classroom lectures. & 4.04 & 43.2 \\
\hline Most of my peers do not take the training seriously. & 3.72 & 33.1 \\
\hline The training was more of a 'talk shop' than real, practical work. & 3.73 & 40.6 \\
\hline I do not have a clear understanding of what I was taught & 4.23 & 46.4 \\
\hline The training is too general and not farm-enterprise specific. & 3.66 & 29.1 \\
\hline $\begin{array}{l}\text { The training bridged the gap between theoretical knowledge acquired in the classroom and } \\
\text { actual field practice. }\end{array}$ & 3.69 & 7.2 \\
\hline The training provided relevant industrial skills and experience relevant to my course of study. & 4.14 & 1.8 \\
\hline $\begin{array}{l}\text { The training has provided me with skills that I am likely to need in my work situation post- } \\
\text { graduation. }\end{array}$ & 4.24 & 1.4 \\
\hline The training provided ample opportunity of handling farm machinery and equipment. & 3.92 & 6.5 \\
\hline The training was not different from my normal classroom theoretical work. & 3.00 & 16.2 \\
\hline The students were not adequately orientated about the programme. & 3.14 & 11.9 \\
\hline Most of the facilitators are not well grounded in practicalities & 3.40 & 22.3 \\
\hline $\begin{array}{l}\text { PAE did not offer opportunities to interact with small- scale farmers to appreciate their } \\
\text { problems. }\end{array}$ & 2.94 & 11.5 \\
\hline Methods of teaching practical skills were laborious. & 3.06 & 17.3 \\
\hline Teachers failed to use a combination of instructional strategies. & 3.68 & 24.8 \\
\hline
\end{tabular}

Grand mean $=3.67$

Source: Field survey (2018)

Overall, results indicated a highly favorable disposition towards PAE amongst the students. Huq and Gilbert (2013) opined that real-life experiences generate meaningful applications of theories. This finding is in line with that of Rudebjer, Temu and Kung'u Bokelman and 
Creative Commons User License: CC BY-NC-ND

Abstracted by: EBSCOhost, Electronic Journals Service (EJS),

Google Scholar, Journal Seek, Scientific Commons,

Food and Agricultural Organization (FAO), CABI and Scopus

http://eoi.citefactor.org/10.11226/v23i1
Journal of Agricultural Extension

Vol. 23 (1) January, 2019

ISSN(e): 24086851; ISSN(Print); 1119944X

http://journal.aesonnigeria.org

http://www.ajol.info/index.php/iae

Email: editorinchief@aesonnigeria.org

Adamseged (2016), who suggested that pragmatic working relations should exist between the Faculty of Agriculture, agriculture undergraduates and various external stakeholders in the food chain industry. The integrated approach, according to Spielman (2012) requires that the tertiary-level agricultural education system produce more, and better trained, professionals to fill the ranks of the public research, extension, and rural administration systems.

There was a strong perception by more than half $(52 \%)$ of the students that PAE enhanced their practical skills acquisition. Contemporary studies have shown positive correlations between participation in practical courses, skills and employment outcomes (Tran, 2017). Qenani, MacDougall and Sexton's (2014) empirical study revealed that perceived employability increased 1.42 times for individuals possessing field-specific technical skills, which is higher than the employability potential of individuals possessing generic skills, such as oral communication (1.38 times greater) and critical thinking (1.34 times greater).

In total, $67.4 \%$ of students in this study disagreed that the training was more of a 'talk shop' than real, practical work. This is an indication that the PAE to which students were exposed was not only a platform for learning the practice of agriculture, but an opportunity to sharpen the orientation of students towards agricultural enterprises post-graduation. A grand mean of 3.67 confirms that on the average, the disposition of the students towards PAE was positive. This is expected to have a positive impact on the career development and employability of the product of the curriculum.

\section{Involvement of Students' Family Members in Agricultural Enterprises}

Results shown in Table 3 reveal that the majority (57.6\%) agreed that members of their nuclear family were involved in some form of agricultural enterprise. The majority (69.6\%) also agreed that agriculture was one of their key subjects in school, and that the knowledge of agriculture gained at secondary school stimulated their interest in agriculture (56.8\%).

Table 3: Involvement of students nuclear family members in agricultural enterprises

\begin{tabular}{llll}
\hline Involvement of family members in agricultural enterprises & Mean & Ran \\
\hline $\begin{array}{l}\text { Members of my nuclear family are involved in a form of agricultural } \\
\text { enterprise. }\end{array}$ & & 1.72 \\
$\begin{array}{l}\text { Members of my extended family are involved in a form of } \\
\text { agricultural enterprise. }\end{array}$ & & 2.57 & 2 \\
$\begin{array}{l}\text { Agriculture was one of my key subjects at secondary school. } \\
\text { Knowledge of agriculture at secondary school stimulated my }\end{array}$ & 2.02 & 4 \\
interest in agriculture. & & &
\end{tabular}

Source: Field survey (2018)

The results also indicate that the vast majority of agricultural students had family members involved in a form of agricultural activity (entrepreneurial or educational) and that their interest in agriculture stemmed from their exposure to agriculture in their homes. This is an indication that the exposure of students to practical agriculture is more influenced at home than the teaching of agriculture at the secondary schools. There is the need to strengthen the teaching of agriculture in the secondary schools that will be able to complement the home exposure for improve learning. It suggests that practical farming experience gained in the home or school 
Creative Commons User License: CC BY-NC-ND

Abstracted by: EBSCOhost, Electronic Journals Service (EJS),

Google Scholar, Journal Seek, Scientific Commons,

Food and Agricultural Organization (FAO), CABI and Scopus

http://eoi.citefactor.org/10.11226/v23i1
Journal of Agricultural Extension

Vol. 23 (1) January, 2019

ISSN(e): 24086851; ISSN(Print); 1119944X

http://journal.aesonnigeria.org

http://www.ajol.info/index.php/iae

Email: editorinchief@aesonnigeria.org

stimulates an interest in studying agriculture and complements the University's practical training component. The result therefore indicates that the knowledge being taught in the University is in agreement with the prevalent cultural and social practices of the people. It is therefore expected that making impacts on the society will be relatively easy due to less of possible social resistance.

\section{Students Level of Satisfaction with Training}

Results in Table 4 indicate that overall, the training served students' interests well and they derived a significant measure of satisfaction from it. For example, 43.5\% strongly agreed and $41.7 \%$ agreed that the training was a revelation for better, lucrative jobs in the farming industry. About $80 \%$ agreed that they were able to relate the training to theory learned in the classroom, while $86 \%$ also agreed that they gained a lot on the farm where they were exposed to practical activities.

\section{Table 4: Students' level of satisfaction with the training}

\begin{tabular}{|c|c|c|}
\hline Items & Mean & \\
\hline I developed self-confidence after the training in farming. & $4.18^{*}$ & 2 \\
\hline I gained a lot on the farms we were taken to. & $4.14^{*}$ & 3 \\
\hline I was able to relate the training to the theory learned in the classroom. & $4.05^{*}$ & 4 \\
\hline $\begin{array}{l}\text { PAE offers valuable hands-on experience for me as a student interested in } \\
\text { agribusiness post-graduation. }\end{array}$ & $3.94^{*}$ & 8 \\
\hline $\begin{array}{l}\text { PAE will contribute to my success in a career in agribusiness post- } \\
\text { graduation. }\end{array}$ & $3.99^{*}$ & 7 \\
\hline PAE will enhance my agribusiness potential. & $4.01^{*}$ & 6 \\
\hline $\begin{array}{l}\text { The training was an eye opener for better, lucrative jobs in the farming } \\
\text { industry. }\end{array}$ & $4.23^{*}$ & 1 \\
\hline With the training, I can be self-employed in my chosen farming enterprise. & $4.04^{*}$ & 5 \\
\hline
\end{tabular}

${ }^{*}$ satisfied

Source: Field survey (2018)

The assessment of students' satisfaction with the training showed that, overall, the training served their needs well and that they derived a significant measure of satisfaction from the training. Some of their satisfaction derived from their ability to link practical actions with theoretical knowledge already gained. It also enabled them to understand that the agricultural industry comprises vast and lucrative opportunities for career development. The satisfaction with such aspects of practical training could raise levels of motivation (Shahsavar \& Sudzina, 2017) and stimulate venturing into farming as a profession.

\section{Perceptions Regarding Improving PAE}

Table 5 reveals that $64 \%$ agreed that the programme should be more practical than it was. The majority $(73 \%)$ agreed that students should be posted out for experiential learning rather than having experts come to teach them. An appreciable proportion of $61 \%$ felt that evaluations of the programme should be based on students own written reports of the training. 
Creative Commons User License: CC BY-NC-ND

Abstracted by: EBSCOhost, Electronic Journals Service (EJS),

Google Scholar, Journal Seek, Scientific Commons,

Food and Agricultural Organization (FAO), CABI and Scopus

http://eoi.citefactor.org/10.11226/v23i1
Journal of Agricultural Extension

Vol. 23 (1) January, 2019

ISSN(e): 24086851; ISSN(Print); 1119944X

http://journal.aesonnigeria.org

http://www.ajol.info/index.php/jae

Email: editorinchief@aesonnigeria.org

Table 5: Perceptions regarding improving PAE

\begin{tabular}{|c|c|c|}
\hline Statements & Mean & \\
\hline The duration should be increased to not less than 6 months. & 3.09 & 5 \\
\hline $\begin{array}{l}\text { The students should be posted out to the farms for experiential } \\
\text { learning instead of experts coming to teach us. }\end{array}$ & $4.00^{*}$ & 2 \\
\hline $\begin{array}{l}\text { The students should be involved rather than being subjected to a } \\
\text { 'talk shop'. }\end{array}$ & $4.37^{\star}$ & 1 \\
\hline $\begin{array}{l}\text { Evaluation should be students' written self-reports for the } \\
\text { duration of the training. }\end{array}$ & $3.61^{*}$ & 3 \\
\hline The credit hour should be reviewed upward. & 3.27 & 4 \\
\hline
\end{tabular}

${ }^{*}$ Favourable

Source: Field survey (2018)

Notwithstanding the favourable perceptions and general satisfaction with PAE, the majority $(51.2 \%)$ of students perceived that the programme still required some improvement in order to achieve its stated objectives. There are strong indications that students desire more practical activities and less talking. This suggests that the practical activities should be outside the enclave of the university. The majority $(70.3 \%)$ agreed with the idea of undertaking their practical training on farms for a specific number of weeks. Jackson (2015) opined the need for students to participate in real-world activities, in support of the notion of reinforcing universityindustry relationships (Mojarradi \& Karamidehkordi, 2016).

\section{Perceptions Regarding Improved Academic Performance}

Results in Table 6 reveal that the majority $(74.8 \%)$ agreed that PAE enhanced their general understanding of agriculture. However, the results confirm that there may not have been a sufficient level of exposure to practical agriculture, as almost half $(49.3 \%)$ indicated that too much emphasis had been laid on theory rather than on practice. Respondents were, on average, indifferent as to whether practical aspects were lacking in the curriculum $(\overline{\mathrm{x}}=2.84)$, and to whether the duration of training was sufficient for any meaningful skills acquisition $(\overline{\mathrm{x}}=$ 2.76).

Table 6: Perceptions of improved academic performance

\begin{tabular}{|c|c|c|}
\hline Indicators & Mean & \\
\hline Students' exposure to PAE is inadequate. & 3.20 & 2 \\
\hline Too much emphasis is laid on theory rather than practice. & 2.78 & 5 \\
\hline Practical teaching is lacking in the curriculum. & 2.84 & 4 \\
\hline $\begin{array}{l}\text { PAE increases transferability of theory learned in class to } \\
\text { practical on the field. }\end{array}$ & 2.38 & 7 \\
\hline $\begin{array}{l}\text { The period of PAE is too short for any meaningful skill } \\
\text { acquisition. }\end{array}$ & 2.76 & 6 \\
\hline PAE enhanced my understanding of agriculture. & $4.07^{*}$ & 1 \\
\hline PAE would not bridge the skill gap in field practical farmi & 3.13 & 3 \\
\hline
\end{tabular}

${ }^{*}$ Favourable.

Source: Field survey (2018) 
Creative Commons User License: CC BY-NC-ND

Abstracted by: EBSCOhost, Electronic Journals Service (EJS),

Google Scholar, Journal Seek, Scientific Commons,

Food and Agricultural Organization (FAO), CABI and Scopus
Journal of Agricultural Extension

Vol. 23 (1) January, 2019

ISSN(e): 24086851; ISSN(Print); 1119944X

http://journal.aesonnigeria.org

http://www.ajol.info/index.php/iae

Email: editorinchief@aesonnigeria.org

The study also assessed students' perceptions of how much PAE had improved their academic performance. The results reveal that the majority $(74.8 \%)$ agreed that PAE had enhanced their general understanding of agriculture. However, results indicate that there may have been insufficient exposure to practical agriculture, as almost half $(49.3 \%)$ said that too much emphasis was laid on theory rather than practice. This is an indication that there is a need to improve the programme and make it more practical. Respondents were, on average, indifferent as to whether practical aspects were lacking in the curriculum $(\overline{\mathrm{x}}=2.84)$, as well as to the sufficiency of the duration for meaningful skills acquisition $(\overline{\mathrm{x}}=2.73)$. They also disagreed $(\overline{\mathrm{x}}=2.38)$ that PAE increased the transferability of theory learned in class to practical situations in the field. Therefore, there is a need to modify the programme so that it is more practical and enables students to transfer theory to real-world situations. Such changes would no doubt make the programme more effective and improve the skills of agriculture graduates in South Africa.

\section{Categorisation of Respondents' Perceptions, Satisfaction, Improved Performance and Involvement in Agriculture}

Table 7 indicates that more than half $(55.0 \%)$ had favourable perceptions of practical agriculture experience. The majority (51.1\%) expressed a high level of satisfaction, while $66.2 \%$ rated the programme unfavourably for not having a positive effect on their academic performance.

Table 7: Categorisation of respondents based on perceptions, satisfaction, improved performance and involvement in agriculture

\begin{tabular}{llll}
\hline Categories & Percentage & Mean & SD \\
\hline Perception of PAE & & & \\
Unfavourable & 45.0 & 82.87 & 10.49 \\
$\begin{array}{l}\text { Favourable } \\
\text { Perceived satisfaction }\end{array}$ & 55.0 & & \\
Low & 48.9 & 11.24 & 3.84 \\
$\begin{array}{l}\text { High } \\
\text { Perceived improved performance }\end{array}$ & 51.1 & & \\
$\begin{array}{l}\text { Unfavourable } \\
\text { Favourable }\end{array}$ & 66.2 & & \\
Level of involvement in agriculture & 33.8 & 32.23 & 5.36 \\
Low & 53.2 & & \\
High & 46.8 & 18.06 & 4.13 \\
\hline
\end{tabular}

Source: Field survey (2018)

The result is an indication that respondents were favourably disposed to the programme. It however suggests that the programme has not improved over time, and this may not be in the interest of a sustained quality of the programme. Perhaps, if efforts are made to make adjustment to the programme in such a way that enhances the quality, it will take the country some steps closer to achieving food country through enhanced human capital development.

\section{Relationship between Respondents' General Disposition and Satisfaction with PAE}


Creative Commons User License: CC BY-NC-ND

Abstracted by: EBSCOhost, Electronic Journals Service (EJS),

Google Scholar, Journal Seek, Scientific Commons,

Food and Agricultural Organization (FAO), CABI and Scopus

http://eoi.citefactor.org/10.11226/v23i1
Journal of Agricultural Extension

Vol. 23 (1) January, 2019

ISSN(e): 24086851; ISSN(Print); 1119944X

http://journal.aesonnigeria.org

http://www.ajol.info/index.php/iae

Email: editorinchief@aesonnigeria.org

The study established a significant relationship between respondents' general disposition and satisfaction with PAE $(r=0.438)$. There was also a significant relationship between respondents' perceptions of improved performance and their satisfaction.

Table 8: Relationship between respondents' general disposition, agricultural involvement background, improved performance and satisfaction

\begin{tabular}{ll}
\hline Variables & $\mathbf{r}$ \\
\hline General disposition towards PAE & $0.438^{*}$ \\
Involvement & $0.131^{*}$ \\
Perception of improved performance & $0.276^{*}$
\end{tabular}

${ }^{*} \mathrm{P} \leq 0.05$.

Source: Field survey (2018)

The study established a significant relationship between the students' general disposition and their satisfaction with PAE $(r=0.438)$. There was also a significant relationship between respondents' perceptions of improved academic performance and their satisfaction with the programme. These results indicate that the more satisfied the students were, the more favourably disposed they were to the programme. It also indicates that students who perceived the programme to have had an effect on their marks were more satisfied than those who experienced no such effect, suggesting that their expectations were met. The result is in agreement with Expectations Confirmation theory, which argues that expectations coupled with perceived performance lead to post-purchase satisfaction. It establishes the nexus between expectation and satisfaction, positing that if a product outperforms expectations (positive disconfirmation) post-purchase satisfaction will result. If a product falls short of expectations, (negative disconfirmation) the consumer is likely to be dissatisfied. The result further reveals that involvement in agriculture and perceptions regarding improved academic performance have a significant relationship with respondents' levels of satisfaction with PAE. This result could also be an indication that experiences acquired over the duration of the PAE did not fall short of students' expectations. It is therefore a further indication that the practical agricultural training programme is meeting its objective of human capital development for improved agricultural productivity and food security.

\section{Conclusion and Recommendations}

This study substantiates the relevance of PAE as a crucial educational tool for enhancing hands-on practical agricultural knowledge amongst university students, having a positive effect on academic performance and more significantly, on students' skills and technical expertise. PAE plays an important foundational role in building the capacities of agricultural students to become active players in the South African agricultural economy. The high level of satisfaction and the generally positive disposition of students towards the programme, evidenced in this study's findings, affirms the effectiveness of practical training, as it relates to honing students' skills and employability post-graduation. Based on its findings, this study has implications for the evaluation process of the programme, and suggests that the design of the PAE should be off-campus internships on commercial farms for a specific number of weeks. This will provide 
Creative Commons User License: CC BY-NC-ND

Abstracted by: EBSCOhost, Electronic Journals Service (EJS),

Google Scholar, Journal Seek, Scientific Commons,

Food and Agricultural Organization (FAO), CABI and Scopus

http://eoi.citefactor.org/10.11226/v23i1
Journal of Agricultural Extension

Vol. 23 (1) January, 2019

ISSN(e): 24086851; ISSN(Print); 1119944X

http://journal.aesonnigeria.org

http://www.ajol.info/index.php/iae

Email: editorinchief@aesonnigeria.org

the real-world experiential learning that could stimulate students to venture into practical farming post-graduation, and to do well in it.

\section{References}

Abidin, S.A.Z., Jamil, A.H. \& Abdullah, N. (2017). Expectation vs Reality: A Study on the Significance of Practical Training for Future Graduates. Journal of Educational and Social Research, 7(2):141.

Acuña, T.B., Kelder, J.A., Able, A.J., Guisard, Y., Bellotti, W.D., Mcdonald, G., Doyle, R., Wormell, P. \& Meinke. H. (2014). Academic, industry and student perspectives on the inclusion of 'vocational knowledge' in a 'learning and teaching academic standards statement' for agriculture. Journal of Learning Design, 7(2):1-15.

Ayanda, I.F., Yusuf, O.J. \& Salawu, O.L. (2013). Farm practical training programme for agricultural students: Case study of pioneer students, Kwara State University, Malete, Nigeria. Journal of Sustainable Development in Africa, 15(8): 25-41.

Danilevičius, E. (2013). The Strengthening of Learners' Link with Profession as a Factor of Vocational Education Quality Assurance (Lithuanian Agricultural Schools Research). Rural Development.

Deegan, D., Wims, P. \& Pettit, T. (2016). Practical skills training in agricultural education - A comparison between traditional and blended approaches. The Journal of Agricultural Education and Extension, 22(2) :145-161.

Huq, A. \& Gilbert, D.H. (2013). Enhancing graduate employability through work-based learning in social entrepreneurship: A case study. Education + Training, 55 (6): 550-572.

Hulela, K. (2017). The Practice of Scaling Down Practical Assessment Components of Agriculture in Junior Secondary Schools Curriculum: A Synthesis of Teachers Perceptions. Journal of Education and Training Studies, 5(3):43-52.

Jackson, D. (2015). Employability skill development in work-integrated learning: Barriers and best practice. Studies in Higher Education, 40(2): 350-367.

Kipkeme, E., Mose, J., Chumo, C., Kosgei, D., Chepng'eno, W., \& Boit, R. (2015). Contribution of secondary school agricultural knowledge on farmers 'crop and livestock diversification activities in Uasin-Gishu county, Kenya. International Journal of Innovative Agriculture \& Biology Research 3(3):18-26.

Lenke, J.A. (2015). Which way vocational agriculture? Theme article. The Agricultural Education Magazine, November/ December 2015. Available at https://www.questia.com/library/journal/1P3-3957034911/which-way-vocational agriculture. Accessed 12 June 2018.

Mojarradi, G. \& Karamidehkordi, E. (2016). Factors influencing practical training quality in Iranian agricultural higher education. Journal of Higher Education Policy and 
Creative Commons User License: CC BY-NC-ND

Abstracted by: EBSCOhost, Electronic Journals Service (EJS),

Google Scholar, Journal Seek, Scientific Commons,

Food and Agricultural Organization (FAO), CABI and Scopus
Journal of Agricultural Extension

Vol. 23 (1) January, 2019

ISSN(e): 24086851; ISSN(Print); 1119944X

http://journal.aesonnigeria.org

http://www.ajol.info/index.php/iae

Email: editorinchief@aesonnigeria.org

http://eoi.citefactor.org/10.11226/v23i1

Management, 38(2):183-195. National Planning Commission, South Africa. (2013). National development plan vision 2030. An integrated and inclusive rural economy (Chapter 6). https://www.brandsouthafrica.com/governance/ndp/the-nationaldevelopment-plan-a-vision-for-2030.

Niewolny, K.L., Grossman, J.M., Byker, C.J., Helms, J.L., Clark, S.F., Cotton, J.A. \& Jacobsen, K.L. (2016). Sustainable agriculture education and civic engagement: The significance of community-university partnerships in the new agricultural paradigm. Journal of Agriculture, Food Systems, and Community Development, 2(3): 27-42.

Pouris, A. \& Inglesi-Lotz, R. (2014). The contribution of higher education institutions to the South African economy. South African Journal of Science, 110(3-4): 01-07.

Qenani, E., Macdougall, N. \& Sexton, C. (2014). An empirical study of self-perceived employability: Improving the prospects for student employment success in an uncertain environment. Active Learning in Higher Education, 15(3):199-213.

Reece, I. and Walker, S., (2016). Teaching, training and learning: A practical guide. Business Education Publishers Ltd.

Richmond, W.K. (2018). The school curriculum. Routledge.

Rodzalan, S.A. \& Saat, M.M. (2012). The effects of industrial training on students' generic skills development. Procedia-social and behavioral sciences, 56:357-368.

Saliu, O.J., Onuche, U. \& Abubakar, H. (2016). Perception of Kogi State University agricultural students on farming as a career. International Journal of Sustainable Agricultural Research.

Shahsavar, T. \& Sudzina, F. (2017). Student satisfaction and loyalty in Denmark: Application of EPSI methodology. PloS one, 12(12), p.e0189576.

Swarts, M.B., \& Aliber, M. (2013). The 'youth and agriculture problem: Implications for rangeland development. African Journal of Range \& Forage Science, 30(1-2):23-27.

Tang, Y. (2012). The mode of theoretical knowledge and practical knowledge combination: The significance of internship. World Journal of Education, 2(4):55.

Tran, L.H.N. (2017). Developing employability skills via extra-curricular activities in Vietnamese universities: Student engagement and inhibitors of their engagement. Journal of Education and Work, 30(8):854-867.

Tukundane, C., Minnaert, A., Zeelen, J. \& Kanyandago. P. (2015). Building vocational skills for marginalised youth in Uganda: A SWOT analysis of four training programmes. International Journal of Educational Development, 40(2015):134-144.

The United Nations Educational, Scientific and Cultural Organization (UNESCO)., 2012. Youth and skills: putting education to work. The EFA Global Monitoring Report 2012. 
Creative Commons User License: CC BY-NC-ND

Abstracted by: EBSCOhost, Electronic Journals Service (EJS), Google Scholar, Journal Seek, Scientific Commons,

Food and Agricultural Organization (FAO), CABI and Scopus

http://eoi.citefactor.org/10.11226/v23i1

UNESCO Publishing, Paris.

http://unesdoc.unesco.org/images/0021/002180/218003e.pdf. Accessed 12 June 2018.

William, O. (2015). Introduction of core-based subjects in the curriculum of technical and vocational institutions in Ghana: Assessment of its effect on practical training sessions. Journal of Education and Practice, 6(31):28-32.

Wolfgang Bokelmann, Muluken E. Adamseged (2016) Contributing to a better understanding of the value chain framework in developing countries. Invited poster presented the 5th International Conference of the African Association of Agricultural Economists, September 23-26, 2016, Addis Ababa, Ethiopia.

Spielman, D. J. Davis, K. Zerfu, E. Ekboir, J. and Ochieng, C. M. O. (2012). An innovation systems perspectives on tertiary-level agricultural education in sub-Saharan Africa: Evidence from Ethiopia. Ethiopian Journal of Education and Sciences, 7(2):15-32 